\title{
Georg Simmel
}

\section{Storbyerne og det åndelige liv}

Det moderne livs dybeste problem udspringer af individets krav om at bevare sin tilværelses selvstændighed og egenart over for de overmægtige kræfter, som samfundet, den historiske overlevering, den ydre kultur og livets teknik repræsenterer. Den kamp med naturen, som det primitive menneske må føre for $\sin$ kropslige eksistens, antager her sin hidtil seneste form. Det 18. århundrede kan siges at opfordre til befrielse fra alle historisk opståede bindinger inden for stat og religion, moral og $\emptyset$ konomi, for at den oprindeligt gode natur, som hos alle mennesker er ens, kan udvikle sig uden begransninger; det 19. århundrede kan siges - ud over den blotte frihed - at kræve den arbejdsdelte specialisering af mennesket og dets præstationer, en specialisering, som gør den enkelte usammenlignelig og så vidt muligt uundværlig og dog samtidig så meget desto mere afhængig af at blive suppleret af alle andre; Nietzsche ser forudsætningen for individernes fulde udvikling i den enkeltes mest hensynsløse kamp, og socialismen ser den netop i undertrykkelsen af al konkurrence i alle tilfælde virker det samme grundmotiv: subjektets modstand mod at blive nivelleret og forbrugt $i$ en samfundsmæssig-teknisk mekanisme. Hvor man søger efter det indre i det specifikt moderne livs frembringelser, hvor man så at sige søger efter sjælen i kulturens kroppe - sådan som det i dag vil være min opgave i forhold til vore storbyer -, vil svaret måtte undersøge den balance, som sådanne frembringelser etablerer mellem livets individuelle og overindividuelle indhold, de tilpasninger af personligheden, hvorigennem den affinder sig med de magter, der ligger uden for den.

Det psykologiske grundlag, hvorpå storbyens individualitetstype opstår, er den intensivering af nervelivet, som udgår fra den raske og uafbrudte skiften af ydre og indre indtryk. Mennesket er et forskelsvæsen, d.v.s. dets bevidsthed stimuleres gennem forskellen på den øjeblikkelige stimulus i forhold til den forudgående; vedvarende stimuli, ringe forskel imellem dem, tilvænnet regelmæssighed i deres forløb og deres indbyrdes kontraster forbruger så at sige mindre bevidsthed end den raske ophobning af skiftende billeder, den bratte afstand inden for det, som man omfatter med ét blik, uventetheden i de indtryk, der trænger sig på. Idet storbyen netop skaber disse psykologiske betingelser - med hver passage af gaden, med tempoet og mangfoldigheden $\mathrm{i}$ det 
$\emptyset$ konomiske, professionelle, sociale liv -, grundlægger den helt ned i sjælelivets sansemæssige fundamenter, i det bevidsthedskvantum, som den afkræver os i kraft af vores opbygning som forskelsvæsen, en dyb modsætning i forhold til lillebyen og landlivet, med den langsommere, mere tilvante, regelmæssigt flydende rytme i dens sansemæssigt-åndelige livsform.

Herudfra forstår man frem for alt storbysjælelivets intellektualistiske karakter i forhold til lillebyens, der i langt højere grad er indstillet på følelse og følelsesmassige relationer. Thi disse har rod i psykens mere ubevidste lag og vokser meget tidligt frem under konstante tilvænningers rolige regelmæssighed. Forstandens sted er derimod de gennemsigtige, $\emptyset$ verste lag i vores psyke, den er den mest tilpasningsdygtige af vore indre kræfter; for at finde sig til rette med fænomenernes skiften og modsætning behøver den ikke de omformninger og den indre omkalfatring, som ville være nødvendig, hvis den mere konservative følelse skulle tilpasse sig den samme rytme i fænomenerne. Storbytypen - der naturligvis varierer i tusinde individuelle modifikationer skaber sig således et organ, der beskytter mod den rodløshed, som truer den fra strømningerne og diskrepanserne i dens ydre milieu: i stedet for med følelsen reagerer den heroverfor hovedsageligt med forstanden, der får psykologisk fortrinsret på grund af den intensivering af bevidstheden, som opstår af samme årsag. På denne måde flyttes reaktionen på hine fænomener til det psykiske organ, som er mindst følsomt, og som ligger fjernest fra personlighedens dybder.

Denne forstandsmæssighed, der således betragtes som det subjektive livs beskyttelse mod at blive overvældet af storbyen, forgrener sig ud i mangfoldige enkeltfænomener. Storbyerne har altid været pengeøkonomiens centrum, fordi mangfoldigheden og koncentrationen af den økonomiske udveksling her giver byttemidlet en betydning, som det aldrig ville have faet $\mathrm{i}$ forbindelse med den sparsomme landlige udveksling. Pengeøkonomi og forstandens herredømme står i den dybeste sammenhæng. Til fælles har de den rene saglighed $i$ behandlingen af mennesker og ting, hvor en formal retfærdighed ofte forener sig med en hensynsløs hårdhed. Det rent forstandsmæssige menneske står ligegyldigt over for alt egentligt individuelt, fordi der herfra udgår relationer og reaktioner, som man ikke kan komme til bunds i med den logiske forstand - ligesom fænomenernes individualitet ikke indgår i pengeprincippet. Thi pengene spørger kun efter, hvad alle fænomenerne har til fælles, efter bytteværdien, der nivellerer al kvalitet og egenart til spørgsmålet om den blotte kvantitet. Alle følelsesrelationer mellem personerne baserer sig på deres individualitet, mens de forstandsmæssige relationer regner med mennesker som med tal, d.v.s. som med elementer, der i sig selv er ligegyldige, og som kun har interesse svarende til deres objektivt konstaterbare præstationsevne - 
uden den mest præcise punktlighed i aftaler og ydelser ville alt bryde sammen i et uopløseligt kaos.

Hvis alle ure i Berlin pludselig gik forkert i forskellig retning - om blot med en times variation -, så ville byens hele økonomiske og øvrige samfærdsel for en lang tid falde fra hinanden. Dertil kommer tilsyneladende yderligere den store afstand, som gør al venten og kommen forgæves til et uacceptabelt tidsspilde. Således er storbylivets teknik overhovedet ikke tænkelig, hvis ikke alle aktiviteter og gensidige relationer blev indordnet $i$ et fast, overindividuelt tidsskema.

Men også her træder det frem, hvad der alene kan være hele opgaven i disse betragtninger: at der fra ethvert punkt på tilværelsens overflade, hvor meget det end synes at vokse i og frem af denne, kan sænkes et lod ned i sjælens dyb, - at alle de mest banale ydre forhold i sidste ende er forbundet med de endegyldige afgørelser om livets betydning og form. Den præcision, kalkulerbarhed, exakthed, som storbylivets kompleksiteter og dimensioner påtvinger det, står ikke blot i den snævreste sammenhæng med disses penge økonomiske og intellektualistiske karakter, men må nødvendigvis også farve livets indhold og begunstige udelukkelsen af de irrationelle, instinktive, suveræne personlighedstræk og impulser, som selv ønsker at bestemme formen på livet, i stedet for at modtage den udefra som en almen, skematisk præciseret form. Selv om herskesyge eksistenser med sådanne personlighedstræek ingenlunde er umulige $\mathrm{i}$ byen, så står de dog i modsætning til det typiske; herudfra kan man forklare det lidenskabelige had, som naturer som Ruskin og Nietzsche nærer mod storbyen - naturer, som alene finder livets værdi i det udpræget særegne og i det, som ikke alle vil bestemme på samme måde; hos dem vælder derfor fra den samme kilde had mod pengeøkonomi og intellektualisme som had mod storbyen.

De samme faktorer, som således i livsformens exakthed og minutiøse præcision har forenet sig til et mønster af den højeste upersonlighed, virker på den anden side i retning af et mønster, der er højst personligt. Der findes måske intet psykisk fænomen, der så ubetinget er forbeholdt storbyen, som blasertheden. Denne er i første omgang resultatet af de rask skiftende og i deres kontraster tat koncentrerede nervestinuli, hvorfra også intensiveringen af storbyintellektualiteten forekom os at udspringe; derfor plejer dumme og fra begyndelsen åndeligt sløve mennesker da heller ikke at være netop blaserte. Ligesom et umådeholdent nydelsesliv gør blasert, fordi det i så lang tid ophidser nerverne til de stærkeste reaktioner, indtil de tilsidst overhovedet ikke mere udviser nogen reaktion - således aftvinger også mere harmløse stimuli nerverne i den grad kraftige reaktioner på grund af tempoet og kontrasterne i stimulienes skiften, de trækker nerverne så brutalt frem og tilbage, at disse må ind- 
ligesom storbyboeren regner med sine leverandører og kunder, med sine tjenestefolk og tilmed ofte med de personer, som han pligtmæssigt har social omgang med. Heroverfor står karakteren af den mindre gruppe, hvor det uundgålige kendskab til individualiteterne resulterer $i$ en mere følelsesmæssig farvning af adfærden, $i$ at man går ud over den blot objektive afvejning af ydelse og modydelse.

På den økonomiske psykologis område er det væsentlige her, at der under mere primitive forhold bliver produceret for den kunde, som bestiller varen, sådan at producent og kunde gensidigt kender hinanden. Den moderne storby lever derimod næsten fuldstændig af at producere til markedet, d.v.s. til helt ukendte kunder, der aldrig træer inden for den egentlige producents synskreds. På denne måde făr begge parters interesse en ubarmhjertig saglighed; deres forstandsmæssigt kalkulerende økonomiske egoisme behøver ikke frygte for at blive distraheret af personlige relationers imponderabilia. Pengeøkonomien, der dominerer i storbyerne og her har fortrengt de sidste rester af egenproduktion og det umiddelbare varebytte, og som dagligt reducerer bestillingsarbejdet mere og mere, står i så tæt en vekselvirkning hermed, at ingen ville kunne sige, om hin psykiske, intellektualistiske indretning trak i retning af pengeøkonomien, eller om denne var den afgørende faktor for hin psykiske indretning. Sikkert er blot, at storbylivets form er den mest nærende grobund for denne vekselvirkning; hvilket jeg iøvrigt blot vil belægge med den betydeligste engelske forfatningshistorikers udsagn: i løbet af hele den engelske historie har London aldrig handlet som Englands hjerte, ofte som dets forstand og altid som dets pengepung.

I et tilsyneladende ubetydeligt træk på livets overflade samles - ganske karakteristisk - netop disse sjælelige strømninger. Den moderne ånd er blevet stadig mere beregnende. Idealet i naturvidenskaben, som forvandler verden til et regneeksempel, som fastlægger hver del af den i matematiske formler, modsvares af det praktiske livs kalkulatoriske exakthed, som pengeøkonomien har bibragt det; først den har fyldt så mange menneskers dag med at afveje, regne, kalkulere talmæssigt, med at reducere kvalitative værdier til kvantitative.

Gennem pengenes kalkulatoriske væsen er der kommet en præcision, en sikkerhed $\mathrm{i}$ bestemmelsen af ligheder og uligheder, en utvetydighed i aftaler og opgørelser; i det ydre er den et resultat af den almene udbredelse af lommeurene. Det er imidlertid storbyvilkårene, som er såvel årsag til som virkning af dette væsenstræk. Den typiske storbyboers relationer og anliggender er normalt i den grad mangfoldige og komplicerede, og frem for alt: i kraft af ophobningen af så mange mennesker med så differentierede interesser griber deres relationer og aktiviteter ind i hinanden i en så mangeleddet organisme, at 
sætte deres sidste kraftreserve, og - ved at blive i det samme milj $\emptyset$ - får de ikke tid til at samle en ny. Den manglende evne til at reagere på nye stimuli med en dertil svarende energi er netop den blaserthed, som egentlig allerede ethvert storbybarn udviser i sammenligning med børn fra roligere og mindre afvekslende miljøer.

Med denne fysiologiske kilde til den storbymassige blaserthed forener sig den anden, som udgår fra pengeøkonomien. Blaserthedens væsen er ufølsomheden over for forskellene på tingene, ikke $\mathrm{i}$ den betydning, at de ikke bliver opfattet, sådan som det galder for den stupide, men således, at betydningen og værdien $\mathrm{i}$ forskellene på tingene og dermed tingene selv bliver følt som ligegyldige. De fremtræder for den blaserte i en jæunt mat og grå farvning, ingen ting er værd at foretrække frem for en anden. Denne sjælstilstand er den tro subjektive refleks af den fuldt gennemsatte pengeøkonomi; idet pengene måler alle tingenes mangfoldigheder ensartet, udtrykker alle kvalitative forskelle mellem dem gennem kvantitative forskelle, idet pengene med deres neutralitet og indifferens slår sig op til fællesnævner for alle værdier, bliver de den frygteligste nivellerende kraft, de udhuler nådesløst kernen i tingene, deres særegenhed, deres specifikke værdi, deres usammenlignelighed. De svømmer alle med den samme specifikke vægt i den stadigt fremadglidende pengestr $\varnothing \mathrm{m}$, ligger alle på det samme niveau og adskiller sig kun gennem størrelsen af det areal de dækker. I det enkelte tilfælde kan denne farvning eller snarere affarvning af tingene, der sker ved deres ækvivalering med pengene, være umærkeligt lille; men den er vokset op til en meget mærkbar størrelse i det forhold, som den rige har til genstande, der kan erhverves for penge, ja måske allerede i den helhedskarakter, som den almene holdning nu tildeler disse genstande.

Derfor er de egentlige hjemsteder for blasertheden også storbyerne, penge$\emptyset$ konomiens hoveddomiciler, hvor tingenes salgbarhed trænger sig på i et helt andet omfang end under mindre forhold. I blasertheden kulminerer på sin vis resultatet af den koncentration af mennesker og ting, som stimulerer individet til dets højeste nervemæssige prastation; gennem den rent kvantitative for$\emptyset$ gelse af de samme betingelser slår dette resultat om i sin modsætning, i dette ejendommelige tilpasningsfænomen, som blasertheden er, hvor nerverne opdager, at deres sidste mulighed for at affinde sig med storbylivets indhold og form består i, at de afstår fra at reagere på dem - bestemte typers selvopretholdelse for den pris, at hele den objektive verden devalueres, hvilket så $\mathrm{i}$ sidste ende uundgåeligt trækker den subjektive personlighed ind i en følelse af en lignende devaluering.

Mens subjektet selv må finde sig til rette med denne eksistensform, forlanger dets selvopretholdelse i forholdet til storbyen, at det antager en ikke mind- 
re negativ social holdning. Storbyboernes mentale holdning til hinanden vil man formelt skulle beskrive som reserverethed. Hvis den vedvarende ydre berøring med utallige mennesker skulle fremkalde lige så mange indre reaktioner, som i lillebyen, hvor man kender næsten enhver man møder og har et positivt forhold til hver enkelt, så ville man blive fuldstændig atomiseret indvendigt $\mathrm{g}$ komme i en helt ubeskrivelig psykisk forfatning. Dels denne psykologiske omstændighed, dels den berettigede mistro, som vi har til de forbipasserende, flygtigt berørende elementer i storbylivet, tvinger os til den reservation, som gør, at vi ofte ikke engang kender årelange naboer af udseende, og som så ofte får os til for lillebyboeren at virke kolde og ufølsomme.

$\mathrm{Ja}$, hvis jeg ikke tager fejl, er indersiden af denne ydre reservation ikke blot ligegyldighed, men derimod - oftere end vi gør os det klart - en svag aversion, en gensidig fremmedhed og frastødning, som - hvis der på en eller anden måde opstod en tæt berøring - i samme øjeblik straks ville slå ud i had og kamp. Den indre organisation i en samfærdsel af disse dimensioner beror på et yderst varieret hierarki af sympatier, indifferenser og aversioner af den flygtigste såvel som af den mest vedvarende karakter. Ligegyldighedens område er i den forbindelse ikke så stort, som det overfladisk kan se ud; vor psykes aktivitet reagerer alligevel næsten på ethvert indtryk fra en andet menneske med en eller anden bestemt følelse, hvis ubevidsthed, flygtighed og forandring den kun synes at kunne neutralisere i en ligegyldighed. Faktisk ville denne sidste være lige så unaturlig for os, som det udflydende $\mathrm{i}$ en gensidig suggestion på må og fă ville være uudholdelig; mod disse to typiske farer i storbyen bliver vi beskyttet af antipatien, den latente antagonisme og forstadiet til den praktiske antagonisme; den frembringer de distancer og afværgeforanstaltninger, uden hvilke denne form for liv overhovedet ikke ville kunne føres: antipatiens omfang og blandingsformer, rytmen i dens opdukken og forsvinden, de former, den antager for at blive tilfredsstillet - dette danner sammen med de $\mathbf{i}$ snævrere forstand enhedsskabende motiver en uopløselig helhed i den storbymæssige livsform: hvad der i denne umiddelbart fremtræder som dissociering er således i virkeligheden blot en af dens elementære socialiseringsformer.

Denne reserverethed med overtonen af skjult aversion fremtræder imidlertid også som form eller iklædning for et langt mere alment åndeligt træk ved storbyen. Denne garanterer nemlig individet en form for og et mål af personlig frihed, hvortil der overhovedet ikke findes noget sidestykke under andre forhold: den går således tilbage til en af de store udviklingstendenser i det sociale liv overhovedet, til en af de få tendenser, for hvilken man kan finde en tilnærmelsesvis ufravigelig formel.

I sociale formationer er det tidligste stadium, der findes i historiske såvel som i aktuelt sig udviklende former, dette: en relativt lille gruppe, med stærk 
afgrænsning mod nærtboende, fremmede eller på en eller anden måde antagonistiske grupper, til gengæld med en så meget desto tættere lukning om sig selv, en gruppe, som kun tillader det enkelte individ et ringe spillerum for udfoldelse af særlige kvaliteter og friere bevægelser under eget ansvar. Således begynder politiske og familiemæssige grupper, partidannelser, religiøse fællesskaber; selvopretholdelsen $i$ helt unge sammenslutninger kræver streng afgrænsning og centripetal enhed og kan derfor ikke indrømme individet frihed og særegenhed $i$ indre og ydre udvikling.

Fra dette stadium går den sociale udvikling samtidig til to forskellige og dog hinanden modsvarende sider. I det omfang gruppen vokser - numerisk, rumligt, i betydning og livsindhold - , i samme omfang løsner dens umiddelbare indre enhed sig, skarpheden i den oprindelige afgrænsning over for andre bliver mildnet gennem gensidige relationer og forbindelser; og samtidig vinder individet bevægelsesfrihed, langt ud over den første, skinsyge afgrænsning, og det vinder en egenart og særegenhed, som arbejdsdelingen i den nu større gruppe giver anledning til og nødvendiggør. Ud fra denne formel har staten og kristendommen, laug og politiske partier og utallige andre grupper udviklet sig, omend naturligvis de særlige betingelser og faktorer i de enkelte tilfælde modificerede det almene skema.

Dette forekommer mig imidlertid også tydeligt iagttageligt i individualitetens udvikling inden for det bymæssige liv. Lillebylivet i antikken såvel som i middelalderen lagde for den enkelte skranker på bevægelse og relationer udadtil, på selvstændighed og differentiering indadtil, hvorunder det moderne menneske ikke kunne ånde - endnu i dag føler storbyboeren, der bliver forsat til lillebyen, en indskrænkning, der i det mindste i sin art er den samme. Jo mindre den gruppe er, som udgør vores milieu, jo mere begrænset de grænseopløsende relationer til andre er, desto mere æengsteligt våger kredsen over individets indsats, livsførelse og holdninger, i desto højere grad ville en kvantitativ og kvalitativ afvigelse sprænge helhedens rammer.

Den antikke polis synes $i$ denne retning helt at have haft lillebyens karakter. Den vedvarende trussel mod dens eksistens fra fjender fra nær og fjern frembragte det snævre sammenhold i politisk og militær henseende, den gensidige overvågning borgerne imellem, den skinsyge fra helhedens side over for den enkelte, hvis særlige liv således blev undertrykt i en grad, som han kun kunne holde sig skadesløs for gennem despoti over for sit hus. Den uhyre bevægelse og intensitet, den enestående farverighed i det athenske liv kan måske forklares ud fra, at et folk af uforligneligt individuelt anlagte personligheder kæmpede mod det stadige indre og ydre tryk fra en afindividualiserende lilleby. Dette fremkaldte en atmosfære af anspændthed, hvorunder de svagere blev holdt nede og de stærke blev stimuleret til lidenskabelig selvhævdelse. Og netop på 
denne måde kom i Athen det til blomstring, som man - uden nøjagtigt at kunne omskrive det - må betegne som »det alment menneskelige« $\mathrm{i}$ vor arts andelige udvikling.

Thi dette er den sammenhæng, hvis saglige såvel som historiske gyldighed her bliver hævdet: de allervideste og mest almene indhold og former i livet er intimt forbundet med de allermest individuelle; begge har deres fælles forstadium og også deres fælles modstander i snævre formationer og grupperinger, hvis selvopretholdelse får dem til at sætte sig til modværge mod både det omfattende og almene uden for dem som mod det frit bevægelige og individuelle inden for dem. Den »frie « mand i feudaltiden var den, der stod under landretten, d.v.s. under den ret, der omfattede den største sociale gruppe, men den mand var ufri, hvis ret kun fandtes i et feudalforbunds snævre gruppe, hvor landretten ikke gjaldt. På samme måde er i dag storbyboeren - i en psykologisk og forfinet forstand - »fri« i modsætning til de småligheder og fordomme, som gør lillebyboeren bornert. Thi den gensidige reservation og ligegyldighed, - store gruppers åndelige livsbetingelser - bliver i sine konsekvenser for individets uafhængighed aldrig følt stærkere end i storbyens tætteste vrimmel, fordi først den kropslige nærhed og tranghed rigtig anskueligg $\varnothing \mathrm{r}$ den pyskiske distance; det er åbenlyst kun bagsiden af denne frihed, når man intetsteds føler sig så ensom og forladt, som netop i den storbymæssige vrimmel; for ligesom det gælder iøvrigt, er det ingenlunde nødvendigt, at menneskets frihed afspejler sig $\mathbf{i}$ dets følelsesliv som et velbefindende.

Det er ikke kun områdets og befolkningens umiddelbare størrelse, som - på grund af den verdenshistoriske korrelation mellem udvidelse af gruppen og af den personlige, indre-ydre frihed - gør storbyen til denne friheds hjemsted. Idet de griber ud over dette anskuelige omfang har storbyerne også været hjemstederne for kosmopolitismen. Sammenligneligt med den form, en formue udvikler sig efter - hinsides en vis størrelse synes rigdommen at vokse i stadig raskere progression og ligesom af sig selv -, vokser i byen horisonten, de økonomiske, personlige, åndelige relationer og deres ideelle territorium som i geometrisk progression, så snart en vis grænse bare én gang er blevet overskredet; enhver opnået dynamisk udvidelse af territoriet bliver et trin på ikke en lignende, men en endnu større efterfølgende udvidelse; fra hver tråd, der spinder sig ud fra den, vokser da ligesom af sig selv stadig nye tråde, ligesom tilsvarende indadtil $\mathrm{i}$ byen jordrentens unearned increment $\mathrm{på} \mathrm{grund} \mathrm{af}$ den blotte trafikforøgelse helt af sig selv tilfører ejendomsbesidderen st $\varnothing$ rre fortjeneste.

På dette punkt slår livets kvantitet meget umiddelbart om i kvalitet og karakter. Lillebyens livssfære er i det væsentlige afgrænset i og med sig selv. For storbyen er det afgørende, at dens indre liv i bølgebevægelser strakker sig ud 
over et videre nationalt og internationalt område. Weimar er ikke et eksempel på det modsatte, fordi dens betydning nu engang var knyttet til enkelte personligheder og døde med dem, mens storbyen netop er karakteriseret af sin grundlæggende uafhængighed selv af de mest betydningsfulde enkeltpersonligheder - modstykket til og prisen for den uafhængighed, som den enkelte nyder i den.

Det mest betydningsfulde træk ved storbyen ligger i denne funktionelle størrelse hinsides dens fysiske grænser; og denne funktion virker igen tilbage og giver dens liv vægt, betydningsfuldhed, ansvar. Ligesom et menneske ikke slutter med sin krops grænser eller med det område, som det umiddelbart dækker med sin aktivitet, men først med summen af de virkninger, som tidsligt og rumligt udgår fra det: således består også en by først af helheden af de virkninger, som rækker ud over dens umiddelbart givne skikkelse. Først dette er dens virkelig omfang, hvori dens eksistens kommer til udtryk.

Allerede dette peger på, at den individuelle frihed, som er det logiske og historiske komplement til denne udstrækning, ikke kun bør forstås i negativ forstand, som blot bevægelsesfrihed og bortfald af fordomme og filistrøse træk; det grundlæggende ved den er dog, at den særegenhed og usammenlignelighed, som enhver natur i sidste ende et eller andet sted besidder, kommer til udtryk i livsformen. At vi følger vores egen naturs love - og sådan er jo frihed -, bliver for os selv og andre først helt anskueligt og overbevisende, når denne naturs udtryk faktisk adskiller sig fra andres; først vores uforvekslelighed med andre beviser, at vores eksistensform ikke er påtvunget os af andre.

Byerne er først og fremmest dèr, hvor den højeste økonomiske arbejdsdeling findes; de frembringer i denne henseende så ekstreme fænomener, som det i Paris indbringende erhverv at være Quatorzième: personer, lokaliserbare ved skilte ved deres lejligheder, som ved middagstid holder sig parat i en passende påklædning for hurtigt at blive tilkaldt dertil, hvor der $\mathbf{i}$ et selskab er tretten til bords. Nøjagtigt svarende til sin udstrækning frembyder byen i stadig højere grad de afgørende betingelser for arbejdsdelingen: en gruppe, som i kraft af sin størrelse er disponeret for en højst varieret mangfoldighed af ydelser, mens samtidig koncentrationen af individer og deres kamp om kunderne tvinger den enkelte til den specialisering i ydelsen, der gør, at han ikke så let kan fortrænges af en anden.

Det afgørende er, at bylivet har forvandlet overlevelseskampen med naturen til en kamp mellem menneskene, at den gevinst, man kæmper om, her ikke kommer fra naturen, men fra mennesket. For her ligger ikke kun den netop antydede kilde til specialiseringen, men det dybere forhold: den udbydende må fors $\emptyset$ ge at fremkalde nye og stadig mere særegne behov hos den ombejlede. Nødvendigheden af at specialisere ydelsen for at finde en indkomstkilde, der endnu ikke er udtømt, en funktion, der vanskeligt erstattes, trakker i retning af 
differentiering, forfinelse, forøgelse af publikums behov, hvilket klart må føre til voksende personlige variationer inden for dette publikum.

Og dette fører over til den i snævrere forstand åndelige individualisering af psykiske egenskaber, som byen foranlediger til proportionalt med dens størrelse. En række af årsager hertil foreligger. Først og fremmest vanskeligheden ved under storbylivets dimensioner at gøre sin egen personlighed gældende. Hvor den kvantitative forøgelse af betydning og energi når sin grænse, griber man til at skille sig ud kvalitativt, for på denne måde ved at pirre følsomheden for forskelle at vinde den sociale gruppes bevidsthed: dette fører så i sidste ende videre til de tendentiøse mærkværdigheder, til særegenhedens specifikt storbymæssige extravagancer, til kapricen, til det prætentiøse, hvis betydning slet ikke mere ligger i en sådan adfærds indhold, men alene $\mathrm{i}$ dens måde at være anderledes på, at stille sig frem og derigennem gøre sig bemærket - for mange typer går endelig vejen til at bevare en vis form for selvrespekt og til bevidstheden om at udfylde en plads via de andres bevidsthed. I samme retning virker et usynligt moment, der i sine sammenfattende virkninger dog udmærket kan konstateres: at den enkelte kun får korte og sjældne møder med andre - sammenlignet med den omgang, der findes i den lille by. På dette område er nemlig fristelsen til at føre sig frem pointeret, koncentreret og så karakteristisk som muligt langt mere nærliggende, end hvor et hyppigt og langvarigt samvær sørger for at give den anden et utvetydigt billede af personligheden.

Den dybeste grund til, at storbyen fremhæver tendensen til den mest individuelle personlige eksistens - uanset om det altid sker med rette eller med succes - forekommer mig at være denne: udviklingen i den moderne kultur er karakteriseret af dominansen af, hvad man kan kalde den objektive ånd over den subjektive; d.v.s., i sproget som i juraen, i produktionsteknikken som i kunsten, i videnskaben som i det huslige miljøs genstande er der legemliggjort en sum af and, hvis daglige forøgelse subjekternes åndelige udvikling kun meget ufuldstændigt og i stadig større afstand kan følge. Ser vi f.eks. ud over den uhyre kultur, som i de sidste hundrede år har manifesteret sig i ting og erkendelser, i institutioner og bekvemmeligheder, og sammenligner vi individernes kulturfremskridt $\mathbf{i}$ den samme periode hermed - i det mindste i de højere sociale lag -, så viser der sig en forfærdende vaekstforskel mellem de to, ja på mange punkter snarere et tilbageskridt $i$ individemes kultur med hensyn til det åndelige, til finhed, idealisme. Denne diskrepans er i det vasentlige et resultat af voksende arbejdsdeling; for en sådan kræver af den enkelte en stadig mere énsidig præstation, hvis højeste optimering ret ofte lader hans personlighed som helhed forkrøble. I hvert fald er individet mindre og mindre den objektive kulturs overhåndtagen voksen. Måske ikke så meget bevidst som i 
praksis og i den dunkle totalfølelse, som udgår derfra, er individet reduceret til en quantité negligeable, til et støvkorn over for en uhyre organisation af ting og kræfter, som gradvis spiller individet alle fremskridt, åndelige fænomener, værdier af hånden og overfører dem fra det subjektives form til en form, der tilhører et rent objektivt liv.

Det er kun nødvendigt at henvise til, at storbyerne er skuepladserne for denne kultur, der vokser ud over alt personligt. Her fremtræder i bygninger og læreanstalter, i den rumbesejrende tekniks vidundere og bekvemmeligheder, $\mathrm{i}$ samfundslivets strukturer og i statens synlige institutioner en så overvældende mængde af krystalliseret, upersonligt formet ånd, at personligheden så at sige ikke kan stå sig heroverfor. Livet bliver på den ene side gjort uendeligt let, idet impulser, interesser, midler til at udfylde tiden og bevidstheden tilbyder sig fra alle sider og trækker personligheden ind i en strøm, hvor der knap nok er brug for selv at foretage svømmebevægelser. På den anden side sammensættes livet dog mere og mere af disse upersonlige former for indhold og underholdning, som ønsker at fortrænge de egentligt personlige nuancer og usammenlignelige forhold; så netop for at redde dette personlige, må det frembyde en ekstrem særegenhed og orginalitet; det må overdrive det for overhovedet at kunne høres, også af det selv. Den individuelle kulturs atrofi i kraft af den objektive kulturs hypertrofi er en grund til det forbitrede had, som fortalerne for den yderste individualisme - først og fremmest Nietzsche - nærer over for storbyerne; men også en grund til at de netop i storbyerne elskes så lidenskabeligt, at de netop for storbyboeren synes at være forkyndere og forløsere af hans mest utilfredsstillede længsel.

Hvis man ser på det historiske aspekt i disse to former for individualisme, som bliver fremelsket af storbyens kvantitative forhold: den individuelle uafhængighed og udformningen af personlig særegenled, antager storbyen en helt ny værdi i åndens verdenshistorie. Det 18 . århundrede fandt individet $i$ undertrykkende, efterhånden meningsløse bindinger af politisk og agrar, laugsmæssig og religiøs art - indskrænkninger, som påtvang mennesket en på én gang unaturlig form og forlængst uretfærdige uligheder. I denne situation opstod råbet om frihed og lighed - troen på individets fulde frihed til at bevæge sig $\mathrm{i}$ alle sociale og andelige forhold, som med det samme ville lade den fælles ædle kerne hos alle træde frem, sådan son naturen havde lagt den i enhver og som samfundet og historien blot havde forkvaklet. Ved siden af dette liberalismens ideal voksede i det 19. arhundrede, gennem Goethe og romantikken på den ene side, på den anden side gennem den økonomiske arbejdsdeling, et yderligere ideal frem: individerne, som var befriet fra de historiske bindinger vil nu også adskille sig fra hinanden. Ikke mere det »almene menneske« i hver enkelt, men netop kvalitativ individualitet og ufor- 
vekslelighed er nu bærere af dets værdi. I kampen mellem og i de vekslende kombinationer af disse to måder at anvise subjektet dets rolle inden for helheden forløber vor tids ydre så vel som indre historie.

Det er storbyemes funktion at levere skuepladsen for de to kræfters strid og fors $\emptyset \mathrm{g}$ på forening, idet deres særlige betingelser har vist sig som anledninger til og stimuli for udviklingen af dem begge. På denne måde vinder storbyerne en helt enestående, $i$ uoverskuelige henseender frugtbar plads i udviklingen af den psykiske eksistens, de viser sig som en af de store historiske strukturer, hvori de modstridende, livsomfattende strømninger ligesom med lige ret finder sammen og udfolder sig. Dermed træder de - hvadenten deres enkelte fænomener berører os sympatisk eller antipatisk - helt uden for den sfære, hvor dommerens attitude sømmede sig. Idet sådanne kræfter er vokset ind i hele det historiske livs rod såvel som krone - det liv som vi tilhører i en celles flygtige eksistens - er vores opgave ikke at anklage eller at tilgive, men kun at forstå.*

* Indholdet i dette foredrag stammer ifølge sin natur ikke fra en litteratur, der kan anføres. Grundlaget for og udfoldelsen af dets kulturhistoriske hovedtanker er givet i min Philosophie des Geldes.

Oversat af Jorgen Holmgaard fra Georg Simmel: Das Individuum und die Freiheit, Berlin 1984. Foredraget blev trykt forste gang 1903. 